\title{
Differential growth of the barnacle Notobalanus flosculus (Archaeobalanidae) onto artificial and live substrates in the Beagle Channel, Argentina
}

Received: 25 August 2004/ Revised: 16 March 2005/ Accepted: 16 March 2005/Published online: 1 June 2005 (C) Springer-Verlag and AWI 2005

\begin{abstract}
In the Beagle Channel, southern South America (ca. $55^{\circ} \mathrm{S} 67^{\circ} \mathrm{W}$ ), about $20 \%$ of false king crabs (Paralomis granulosa) $>80 \mathrm{~mm}$ carapace length are fouled with the barnacle Notobalanus flosculus. To evaluate differences in growth rates of barnacles attached to artificial and live substrates, clay tiles were anchored as collectors to the bottom at two different sites in the Beagle Channel in September 1996: in Ushuaia harbour (low currents and high levels of suspended matter) and around the Bridges Islands (strong currents and low level of suspended matter). Another set of collectors was deployed at the same sites in October 1998 to collect barnacles for histological studies. Tiles were removed from each place, approximately, on a monthly basis. Carapaces of $P$. granulosa with the epizoic N. flosculus were sampled between November 1996 and 1997, and between March 1998 and September 1999, to study sexual maturation of barnacles. Growth of barnacles was compared between the collectors and P. granulosa carapaces following a qualitative approach. A sexual maturity scale was defined, based on the stage of development of the female reproductive apparatus of
\end{abstract}

Communicated by H.-D. Franke

L. A. Venerus · J. A. Calcagno - D. E. Nahabedian

Facultad de Ciencias Exactas y Naturales,

Depto. de Ecología, Genética y Evolución,

Universidad de Buenos Aires, Lab. 64, $4^{\circ}$ Piso, Pab. II,

Ciudad Universitaria, C1428EHA Buenos Aires, Argentina

G. A. Lovrich

Consejo Nacional de Investigaciones Científicas y Técnicas,

Centro Austral de Investigaciones Científicas, V9410BFD Ushuaia,

Tierra del Fuego, Argentina

Present address: L. A. Venerus ( $\square)$

Consejo Nacional de Investigaciones Científicas y Técnicas,

Centro Nacional Patagónico,

Blvd. Brown s/n, U9120ACV

Puerto Madryn, Chubut, Argentina

E-mail: leo@cenpat.edu.ar

Tel.: + 54-02965-451024

Fax: + 54-02965-454143
$N$. flosculus. Growth rate of barnacles was highest in the harbour, intermediate on $P$. granulosa, and lowest around the Bridges Islands. Presence of oocytes was registered only in epizoic barnacles, suggesting that at least a proportion of these individuals is able to spawn on the carapaces. The potential advantages of settling on a living substrate, namely increased availability of food particles and decreased predation risks are discussed.

Keywords Marine epibiosis - False king crab ·

Paralomis granulosa $\cdot$ Sexual maturity $\cdot$ Cirripedes

\section{Introduction}

In the Beagle Channel, Notobalanus flosculus (Darwin 1854) (Thoracica, Archaeobalanidae) is a frequent epibiont on the lithodid Paralomis granulosa (Jacquinot 1847) and Lithodes santolla (Molina 1782), and is also occasionally found on the brachyurans Eurypodius latreillei Guérin 1828 and Peltarion spinosulum (White 1843) (Calcagno and Lovrich 2000). The presence of $N$. flosculus onto $P$. granulosa was suggested as an indicator of the skip molting of the largest crabs. $N$. flosculus settle typically in November and December, and male $P$. granulosa molt mostly in December (Lovrich et al. 2003). Mature females molt biennially in November and during the second year of the intermolt period also have epizoic barnacles (Lovrich and Vinuesa 1993). If barnacles settle onto P. granulosa which do not molt in that season, the barnacles will remain on their host up to 13 months. In contrast, on males of the sympatric L. santolla, epizoic $N$. flosculus occur for only 5 months, i.e. from December to April, when the host molts (Lovrich et al. 2002).

The prevalence of $N$. flosculus on the largest ( $>80 \mathrm{~mm}$ carapace length) males of $P$. granulosa in the Beagle Channel was between $15 \%$ and $25 \%$ in the period 1995-1997 (Lovrich et al. 2003). These authors hypothesised that $N$. flosculus benefits from improved 
nutrient conditions when attached to a mobile substrate, or are directly favoured by the nutrient currents created by their hosts, as was suggested by Laihonen and Furman (1986). Moreover, epibiosis on a mobile crab could diminish the predation risk on barnacles (Lovrich et al. 2003). Possible disadvantages for $N$. flosculus are the unstable character of a living substrate (because of molting, other physiological processes such us the production and exudation of toxic metabolites and wastes, death, etc.), and the risk of becoming a victim of predators of the basibiont (Wahl 1989). P. granulosa seems to lack an antifouling mechanism that might impede cyprid colonization of the carapace (Lovrich et al. 2003). As far as we know, cleaning in lithodids appears to be restricted to grooming embryos and gills (Pohle 1989). So, these mechanisms would not represent a potential threat for the settlement of $N$. flosculus cyprids on the carapaces of $P$. granulosa or L. santolla. If $N$. flosculus is actually favoured by settling on false king crabs, the barnacles should be able to spawn before crab molting.

Barnacles have been used as biological markers to understand different aspects of the life histories of basibiont crustaceans. Available studies focused mainly on the molting cycles of the basibionts (Barnes and Bagenal 1951; Paul and Paul 1986; Abelló and Macpherson 1992; Gili et al. 1993; Lovrich et al. 2003), or the behaviour of crabs, such as migrations or permanency in refuges (Abelló et al. 1990). However, information on the biology, especially growth, of the epibionts is scarce (Barnes and Bagenal 1951; Heat 1976; Jeffries et al. 1985; Laihonen and Furman 1986; Venerus 2000).

The aim of this paper is to compare growth among barnacles attached to male $P$. granulosa and those settled on artificial collectors at two different sites in the Beagle Channel. Moreover, we define a sexual maturity scale for $N$. flosculus on the basis of a histological study. We discuss whether epibiosis is advantageous to $N$. flosculus. The potential of $N$. flosculus to reach sexual maturity before crab molting is also discussed.

\section{Methods}

Study site and sampling

The Beagle Channel is located at the southernmost tip of South America and is considered a sub-Antarctic environment. The channel connects the southern Atlantic and Pacific Oceans (Fig. 1). Water temperature follows a well-marked seasonal cycle. Surface temperature ranges between $4.2^{\circ} \mathrm{C}$ in July and $9.8^{\circ} \mathrm{C}$ in January (Balestrini et al. 1998). Our study was performed in the Bahía Ushuaia and around the neighbouring Bridges Islands. Currents are weak in the Ushuaia harbour with a maximum of $2.6 \mathrm{~cm} \times \mathrm{s}^{-1}$. Currents are stronger surrounding the Bridges Islands, fluctuating between $16 \mathrm{~cm} \times \mathrm{s}^{-1}$ and

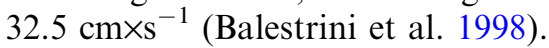

Male P. granulosa were sampled in the Beagle Channel onboard fishing boats between December 1996
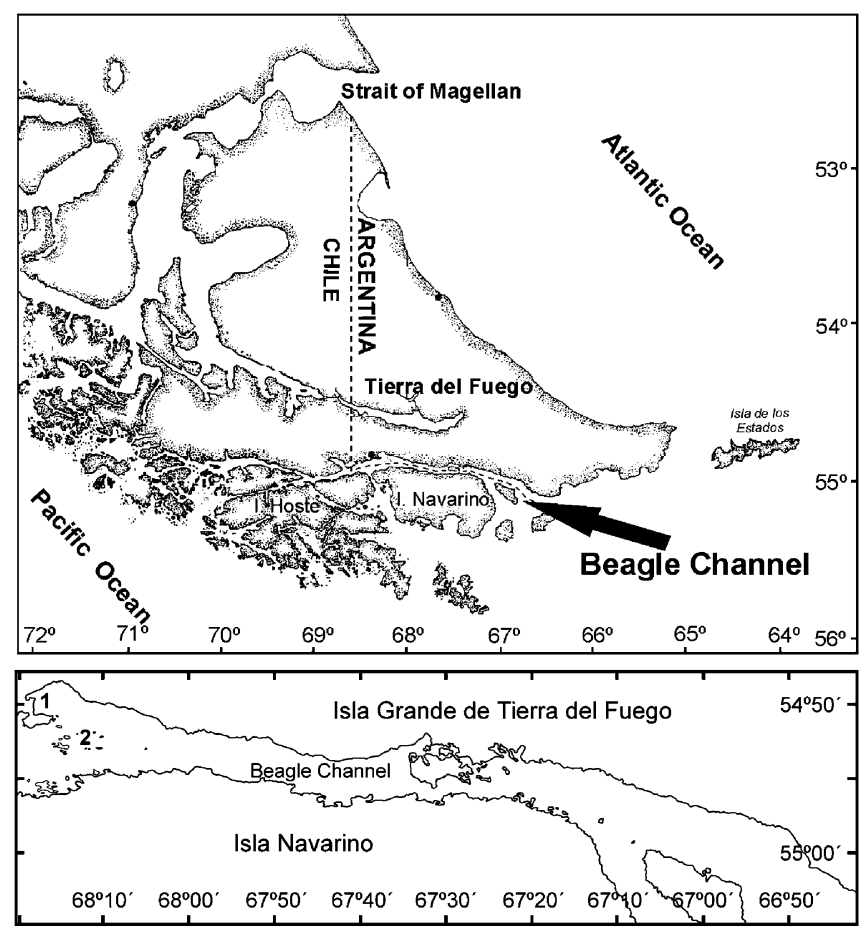

Fig. 1 Location of the study site. Top panel: Map of the southern tip of South America, indicating the Beagle Channel. Bottom panel: More detailed map. 1 = Ushuaia harbour; $2=$ Bridges Islands

and December 1997 (one sample per month, except in April), and between March 1998 and September 1999 (samples collected every 2-3 months). During the fishing season (January-October) and during a survey for stock assessment in December 1996, samples were collected with commercial conical traps deployed at 10-50 m depth. Two additional samples were taken in November 1996, when crabs were caught with six tangle nets of $40 \mathrm{~mm}$ mesh and $25 \mathrm{~m}$ length deployed on the bottom between $2 \mathrm{~m}$ and $30 \mathrm{~m}$ depth. Among crabs that had epizoic barnacles, a total of 109 male $P$. granulosa (1-11 crabs per month) were randomly sampled from the daily commercial catch. Most of these were $80-95 \mathrm{~mm}$ carapace length $(\mathrm{CL})$, because this size class is the most fouled (Lovrich 1997). In the laboratory, carapaces were removed and frozen at $-20^{\circ} \mathrm{C}$. Later, epizoic barnacles were counted, and a subsample of them were removed with a scalpel, fixed in $70 \%$ ethanol and measured.

Clay tiles of $8 \times 16 \times 0.5 \mathrm{~cm}$ were used as artificial collectors for barnacles, each tile with a smooth and a rugged face (see details in Lovrich et al. 2003). Collectors were numbered and arranged in lines of 30 . Lines were deployed at eight different sites in the Beagle Channel on 23 September 1996. No information about the differential distribution of $N$. flosculus in the Beagle Channel was available prior to this study. Therefore, the sites for deploying collector lines were chosen with regard to the dominant current from the southwest (Balestrini et al. 1998), and where $P$. granulosa frequently occurs, particularly at the time of barnacle settlement. Depths of deployment were between $6 \mathrm{~m}$ and $22 \mathrm{~m}$. Collectors were 
checked for newly settled barnacles every 2 weeks in October and November, and every month thereafter. Every month, one to three collectors with barnacles were randomly removed (and replaced by new ones), frozen at $-20^{\circ} \mathrm{C}$ and later fixed in $70 \%$ ethanol. Barnacles were removed from the recovered collectors in the laboratory and then enumerated and measured under a binocular microscope using a gridded eyepiece with a precision of $\pm 0.04 \mathrm{~mm}$. The size of barnacles was estimated from the rostrocarinal length of the shell orifice (hereafter referred to as opercule diameter, DO, sensu Calcagno et al. 1997).

For histological studies, additional eight collectors were deployed on 13 October 1998. Four collectors were placed ca. $150 \mathrm{~m}$ off the coast, near the Ushuaia harbour, whilst the others were deployed around the Bridges Islands. Each collector consisted of a cement block with four U-folded iron rods attached to it. Above each rod, nine clay tiles were firmly tied (36 tiles per collector). Deployment depth was between $6 \mathrm{~m}$ and $14 \mathrm{~m}$. A random number of tiles (between 1 and 5) were removed from each locality at each sampling date.

Water turbidity was assessed using a Secchi disk. Secchi disk depth was registered monthly in the harbour and in the Bridges Islands area between October 1998 and November 1999.

\section{Histological samples}

A total of 28 carapaces of male P. granulosa collected between March 1998 and September 1999 (two to seven carapaces per sampling date) were fixed in $5 \%$ formalin seawater. At each sampling date, a subsample of the largest specimens of $N$. flosculus was carefully removed from carapaces or tiles with a scalpel, to avoid scratching the fragile calcareous basis of the barnacles. Later, only one barnacle for each carapace or tile was randomly chosen from the subsample for the histological study. A total of 49 barnacles from $P$. granulosa carapaces and from tiles were fixed in Bouin solution and preserved in 5\% formalin seawater buffered with borax. Jenkins' fixer solution was used for shell decalcification until $\mathrm{CaCO}_{3}$ was completely dissolved. Finally, the membranous parts were taken apart of the plates, the soft tissues included in $56-58^{\circ} \mathrm{C}$ paraffin, sectioned at 7$10 \mu \mathrm{m}$, stained using the Masson original trichromic method (Gabe 1968), and examined by light microscopy.

We decided to use female reproductive structures to assess sexual maturity because they are easier to detect over time than those of males, particularly after naupliar release. Members of Balanomorpha are typically hermaphrodites and the penis is lost or regresses after the reproductive period (Barnes 1992).

\section{Analyses}

In this paper, we used a qualitative approach to study the growth of $N$. flosculus because modal components in the multimodal size frequency distributions typically overlapped, particularly in the harbour and after May 1997. The goodness of fit of any growth model to this data set would have produced a non-reliable assignation of barnacles to cohorts, in particular when successive settlement events occurred within the same reproductive season.

For a qualitative assessment of differences in growth, we arbitrarily set four size classes: $0-2,2-4,4-6$ and 6$8 \mathrm{~mm} \mathrm{DO}$, that covered the entire range of opercule diameters observed in the samples. Increases in the median of DO over the annual cycle and replacement of individuals in each 2-mm DO size class by others in superior size classes in the subsequent size frequency distributions were used to evaluate growth.

The null hypothesis of equality of turbidity between sites was tested using the permutation test (Manly 1994). The generalisation of the results from this test rests on the assumption of random samples (Manly 1994). We preferred permutation tests because the number of observations was too small for seriously trusting in the power of the tests for normality. The non-parametric Pearson correlation coefficient for evaluating the relationship between DO and sexual maturity stage was calculated following Lengendre and Legendre (1998).

\section{Results}

\section{Growth}

In the Beagle Channel, between November 1996 and December 1997, N. flosculus attained maximum sizes of $6.51,3.98$ and $1.74 \mathrm{~mm}$ DO in the harbour $(n=3,940)$, onto carapaces of $P$. granulosa $(n=2,119)$ and around the Bridges Islands $(n=264)$, respectively (Figs. 2, 3 and 4). The barnacles grew fast from November to April, as is indicated by the changes in the size frequency distributions of DO for both Ushuaia harbour and male P. granulosa carapaces. After May, growth rates seem to decrease (Figs. 2, 3 and 5b). By contrast, size frequency distributions of barnacles from the Bridges Islands remained similar over time (Fig. 4).

In the harbour, the proportion of barnacles in the 0 $2 \mathrm{~mm}$ DO size class dropped abruptly from $100 \%$ to $21 \%$ between November 1996 and February 1997, and remained low $(<11 \%)$ after March 1997, except for the sample collected on 2 June 1997 (Figs. 2 and 5b). In this sample, the proportion of barnacles in the $0-2 \mathrm{~mm} \mathrm{DO}$ size class reached $42 \%$, indicating a recruitment pulse. However, no sign of this pulse was detected in the next size frequency distribution, on 18 June 1997. The first barnacles in the 4-6 $\mathrm{mm}$ DO size class appeared on 25 March 1997 (Fig. 5). This size class contained between $11 \%$ and $48 \%$ of the total number of barnacles collected on the subsequent sampling dates. Only four barnacles attained $>6 \mathrm{~mm}$ DO. This replacement of small or most recent settled barnacles by bigger individuals evidenced the progressive growth of individuals on collectors. 
Fig. 2 Monthly size-frequency distributions of Notobalanus flosculus attached to artificial collectors in the Ushuaia harbour from November 1996 to December 1997, in size classes of $0.17 \mathrm{~mm}$ opercule diameter; $n$ indicates the sample size of barnacles measured. Open bars: 0-2 mm DO; grey bars: 2-4 mm DO; black bars: 4-6 mm DO; stripped bars: 6$8 \mathrm{~mm}$ DO

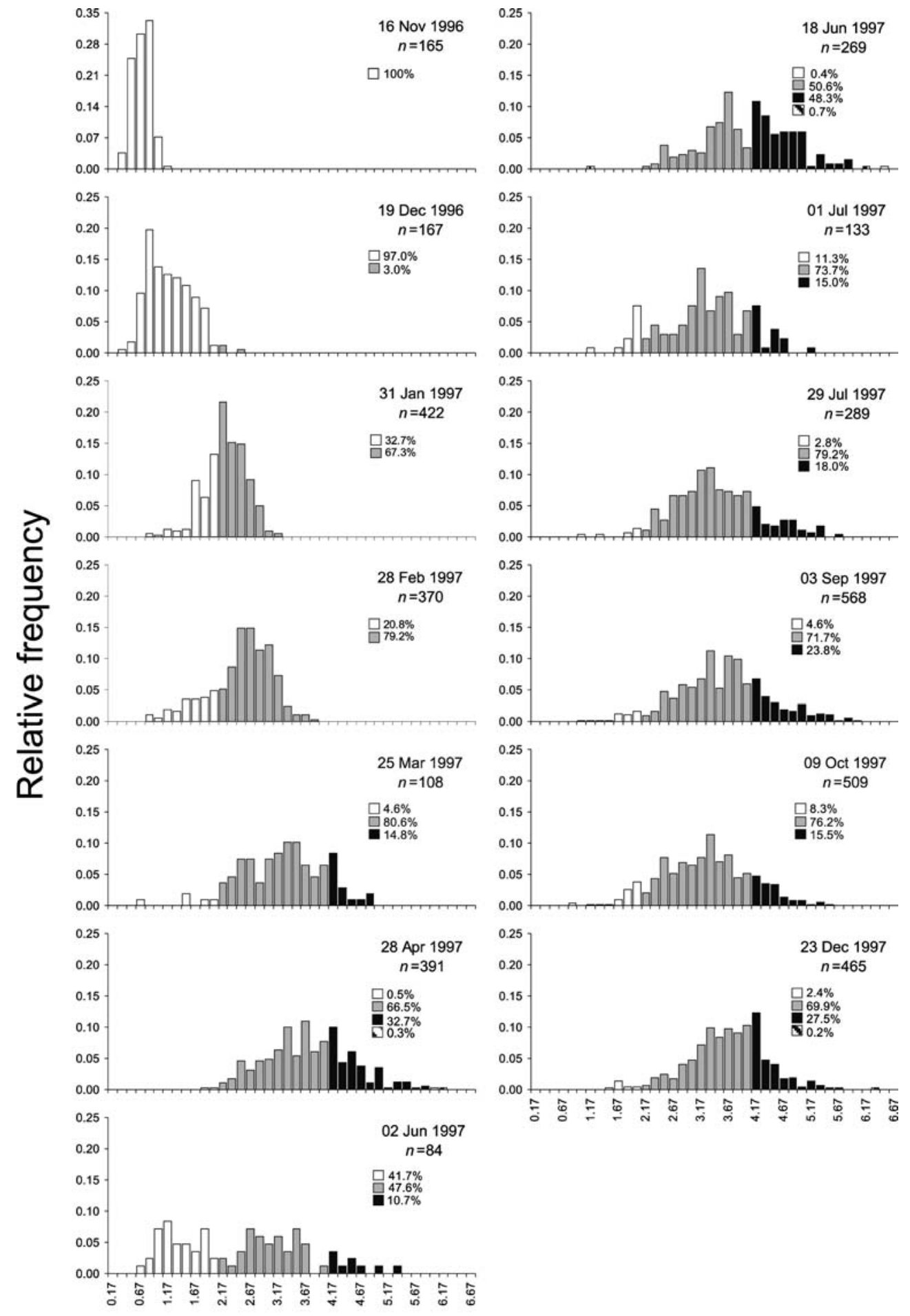

Opercule diameter $(\mathrm{mm})$

Barnacles on P. granulosa were always $<4 \mathrm{~mm}$ DO (Figs. 3 and 5). The proportion of barnacles in the 0 $2 \mathrm{~mm}$ DO size class decreased smoothly between December 1996 and October 1997 (100-14\%), whilst the proportion of barnacles in the $2-4 \mathrm{~mm}$ DO size class increased from January 1997 to October 1997 (Fig. 3). This indicates that epizoic $N$. flosculus also showed continued growth throughout the year (Fig. 5). An exception to this tendency was only observed for the sample of 30 June 1997. In December 1997, only barnacles in the $0-2 \mathrm{~mm}$ DO size class were detected onto four male P. granulosa between $90 \mathrm{~mm}$ and $98 \mathrm{~mm} \mathrm{CL}$. These crabs probably had molted in summer 1996-1997, as it is suggested by the chronology of basibiont molt/ epibiont settlement proposed by Lovrich et al. (2003). The barnacles probably settled between October and 
Fig. 3 Monthly size-frequency distributions of Notobalanus flosculus epibiotic on Paralomis granulosa in the Beagle Channel from November 1996 to December 1997, in size classes of $0.17 \mathrm{~mm}$ opercule diameter; $n$ indicates the sample size of barnacles measured. A total of 33 barnacles attached to the carapaces of three $P$. granulosa sampled on 29 November 1996 was excluded from the growth analysis (see text for details). Open bars: 0-2 mm DO; grey bars: 2-4 mm DO; black bars: excluded barnacles

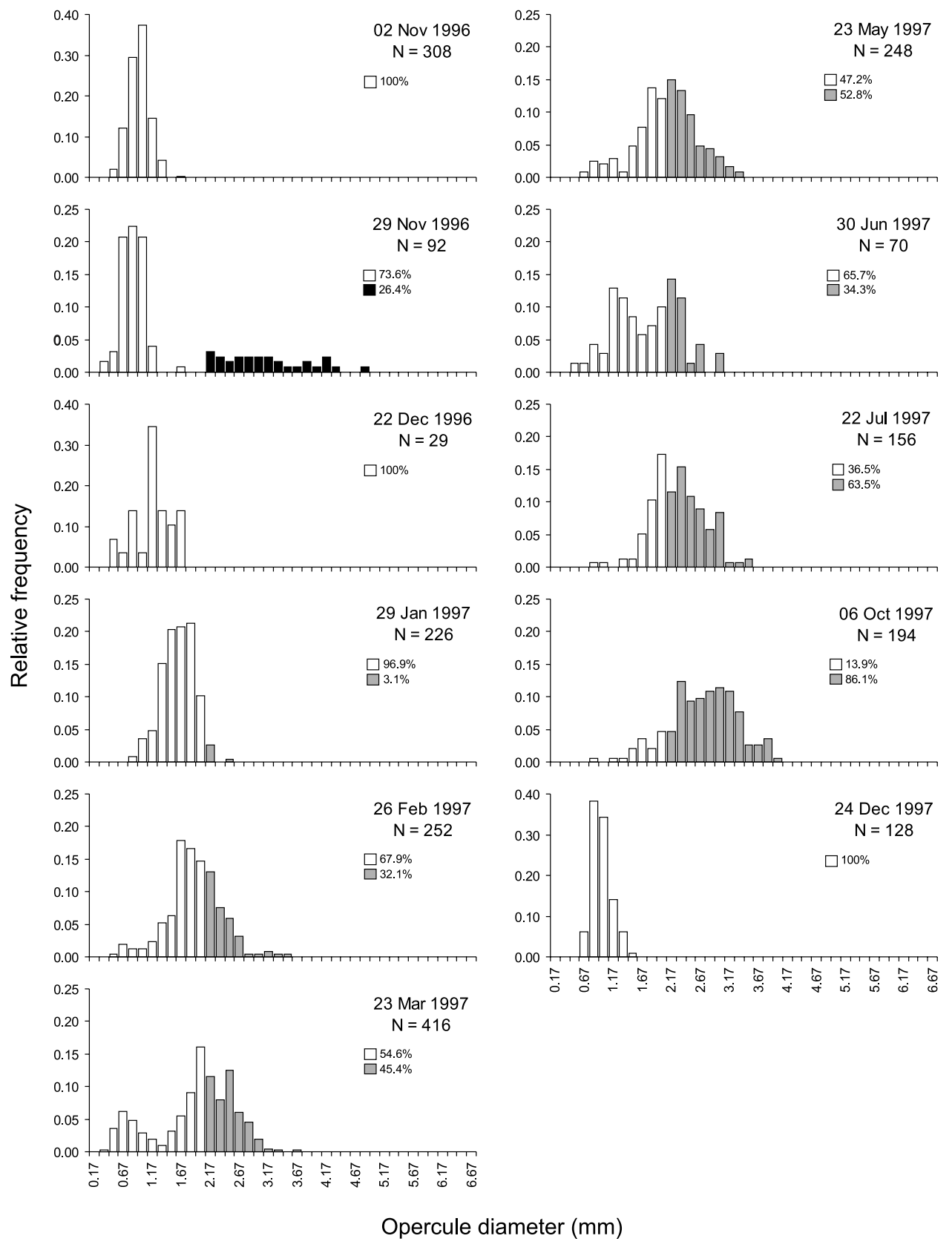

December 1997, on carapaces that had not been colonised by barnacles until then. We excluded from the growth analysis (Fig. 5) a total of 33 epibiont barnacles collected on 29 November 1996 (Fig. 3) because these clearly had settled in a previous period, on crabs that probably had skipped the annual molt the year before. The size of these individuals ranged between $2.16 \mathrm{~mm}$ and $4.81 \mathrm{~mm}$ DO (Fig. 3). The maximum size attained by these set of barnacles was far from that being reached in epizoic barnacles sampled in October 1997, while the two first barnacles from the collectors with a similar size (4.84 mm DO) occurred in the harbour on 25 March 1997 (Fig. 2).

Around the Bridges Islands, in contrast, no barnacles exceeding the range of $0-2 \mathrm{~mm}$ DO were detected in the samples (Figs. 3 and 5). Furthermore, median size of barnacles beyond 31 January 1997 was rather constant (Fig. 5b).

In December 1997, newly settled cohorts of barnacles were detected on the collectors around Bridges Islands and on the carapaces of $P$. granulosa, yet not in the harbour (Figs. 2, 3 and 4). This settlement is the cause of the low median of DO obtained for samples collected on 24 December 1997 on these substrates (Fig. 5). The absence of settlement pulses of barnacles at Ushuaia harbour between November and December 1997 is a puzzling event. Settlement in this site was observed between November and December 1996, and between November and December 1998 (Venerus 2000) on new and clean collectors. Maybe the limited availability of 
Fig. 4 Size-frequency distributions of Notobalanus flosculus attached to artificial collectors around Bridges Islands from November 1996 to December 1997, in size classes of $0.17 \mathrm{~mm}$ opercule diameter; $n$ indicates the sample size of barnacles measured. Open bars: 0-2 mm DO

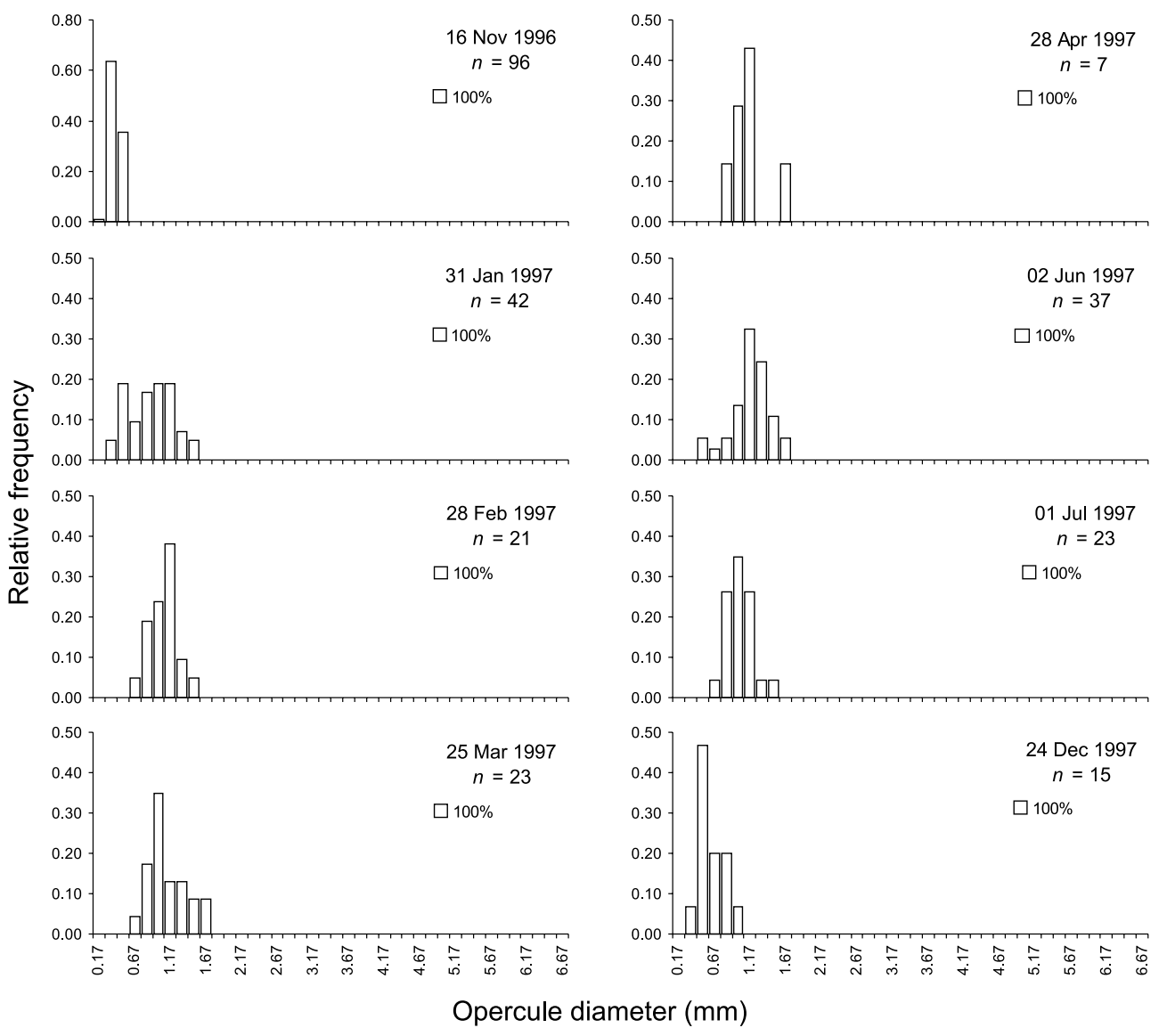

free space on the artificial collectors (barnacle density in December 1997 were 1.07 individuals $\times \mathrm{cm}^{-2}$ ) had prevented any additional settlement.

Between October 1998 and November 1999, Secchi disk depth showed a seasonal pattern in water turbidity, both in the harbour and around Bridges Islands (Fig. 6). Secchi disk depth was maximal in June and July 1999 in the harbour and around the Bridges Islands, respectively, and minimal in February 1999 in both places. Differences in water turbidity was significant (one-tailed Permutation Test for differences between means: $t=5.752 ; P<0.0001 ; n$ iterations $=5,000)$ between the harbour (Mean Secchi disk depth: $4.5 \pm 1.7 \mathrm{~m}$ ) and Bridges Islands (mean Secchi disk depth: $10.2 \pm 3.3 \mathrm{~m}$ ) in that period.

\section{Barnacle sexual maturity}

When $N$. flosculus were $\geq 3$ - to 4-months-old, the basal tissue began to develop within the mantle cavity (Tables 1 and 2). This tissue is a matrix of fibrocytes with undifferentiated mesenchymatic cells (fibroblasts) and storage cells embedded in it. The degree of development of both the basal tissue and the storage cells can be considered a criterion of progressive maturation, prior to oocyte development. Oocytes begin to develop inside finger-like structures, the ovisacs, which contact the basal tissue. We defined a sexual maturity scale with six progressive stages that included three stages preceding oogenesis (Table 1 and Fig. 7). The size ranges of barnacles studied histologically were $2.00-6.01 \mathrm{~mm}$ DO (individuals attached to $P$. granulosa, $n=28$ ), 1.00 $3.51 \mathrm{~mm}$ DO (individuals from collectors in the harbour, $n=14$ ) and $0.75-1.84 \mathrm{~mm}$ DO (individuals from collectors around Bridges Islands, $n=7$ ) (Table 2). For the period March 1998-September 1999, maximum sizes (DO) attained by $N$. flosculus were 5.01, 6.23 and $2.46 \mathrm{~mm}$ in the harbour $(n=1,085)$, onto carapaces of P. granulosa $(n=5,224)$ and in the Bridges Islands $(n=152)$, respectively. Sexual maturity in N. flosculus positively correlated with size (Spearman's rank correlation coefficient: $0.685 ; P<0.001$ ). Almost all maturity stages but stage VI were represented in the samples. No barnacles with oocytes were found among those from collectors extracted and dissected between 5 January and 20 September 1999 (Ushuaia harbour) and between 10 February and 24 May 1999 (Bridges Islands). Mean DO of the epizoic barnacles with maturing or mature oocytes was $4.15 \mathrm{~mm}( \pm 0.98 \mathrm{~mm})$. The smallest individual with oocytes in maturation found was $2.84 \mathrm{~mm}$ DO. Epizoic barnacles with oocytes (stages IV-V) were found in March and August 1998, and in July and September 1999. 
A
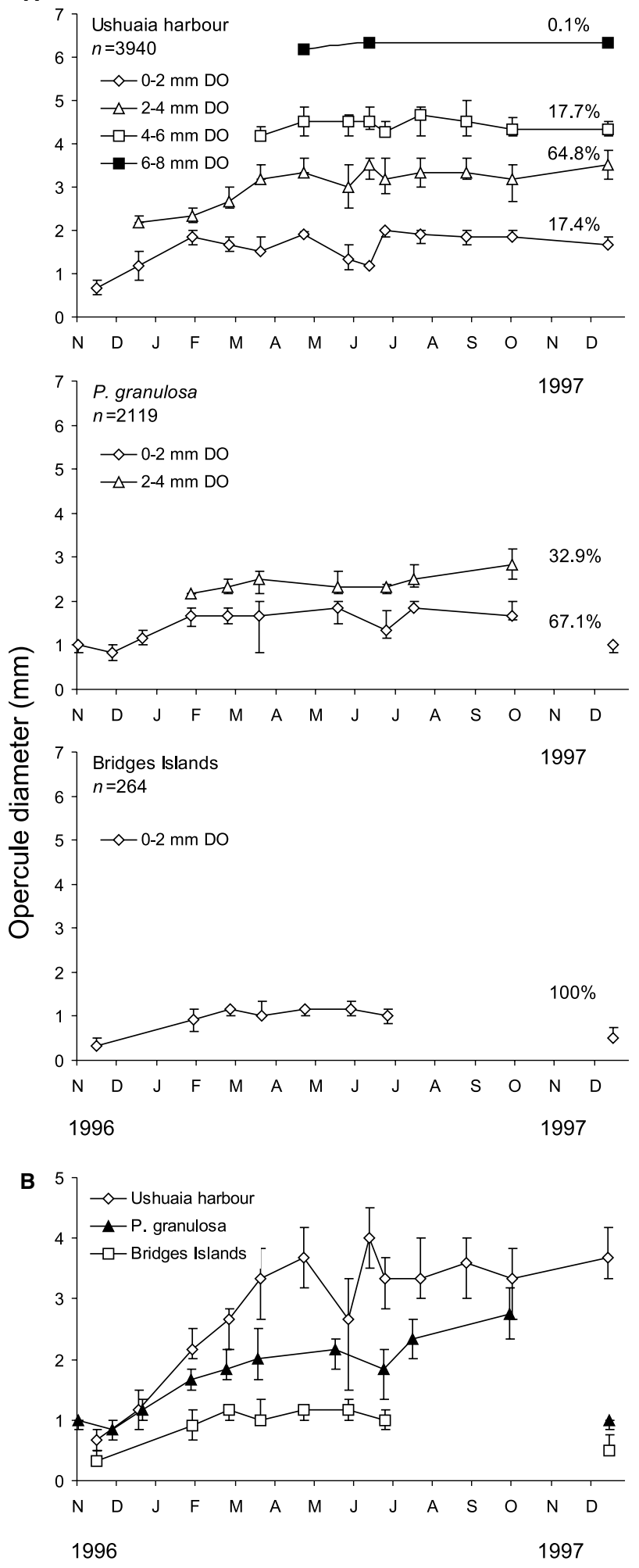

Fig. 5 Median of opercule diameters $( \pm 25 \%$ and $75 \%$ quartiles) of barnacles from Ushuaia Harbour collectors, Paralomis granulosa carapaces and Bridges Islands collectors. a Separately for each site and for epizoic barnacles, in each $2 \mathrm{~mm}$ opercule diameter (DO) size class. b Separately for each site and for epizoic barnacles, and pooled for all $2 \mathrm{~mm}$ DO size classes

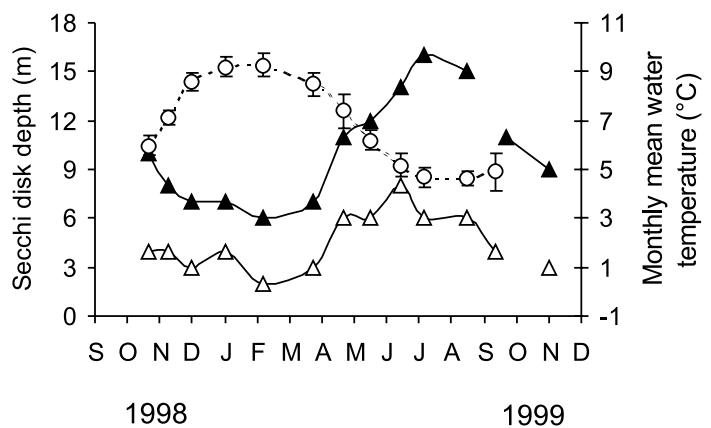

Fig. 6 Secchi disk depths registered in the Ushuaia harbour (open triangles) and around the Bridges Islands (filled triangles), between October 1998 and November 1999; and monthly mean water temperature $( \pm$ SE) in the Beagle Channel between 1994 and 1998 (open circles)

\section{Discussion}

We inferred differences in growth of $N$. flosculus, at two different sites, on artificial collectors and onto P. granulosa carapaces for the period November 1996-December 1997. This conclusion is based on a systematic sampling of barnacles over an entire annual cycle, and on the findings that the most important settlement pulses of $N$. flosculus in the Beagle Channel occur between November and December (Lovrich et al. 2003; Venerus 2000). This implies that barnacles collected at any particular time between November 1996 and December 1997 from both natural and artificial substrates are similar in age. Hence, if $N$. flosculus have a similar sizeat-settlement independently of the type of substratum, and if there is no genetic isolation among nauplii from different sites, the differences in growth observed will be exclusively a consequence of the site of settlement.

Growth rate of $N$. flosculus was highest on collectors in the harbour, intermediate on P. granulosa, and lowest around the Bridges Islands. In contrast to barnacles from the harbour and from $P$. granulosa, individuals from Bridges Islands did not show any increase in DO nor a replacement of individuals in the $0-2 \mathrm{~mm}$ DO size class by larger individuals as the year progressed. These observations suggest that growth of $N$. flosculus around Bridges Islands virtually stopped at the very early age of about 2 months. However, a similar pattern in the size frequency distributions for barnacles from Bridges Islands could also result from $N$. flosculus being size-selected and consumed by predators such as carnivorous snails (Trophon spp.) or sea stars (Cosmasterias lurida) when individuals reach $\sim 1.5-2 \mathrm{~mm}$ DO (Lovrich et al. 2003). Around Bridges Islands, high predation levels are evidenced by the basal marks of lost barnacles left on the tiles. Furthermore, if these individuals achieve substantial somatic growth and predators exert moderate to high levels of prey selection, barnacles will disappear from tiles a few months after settlement. In fact, barnacles virtually disappeared from collectors in the 


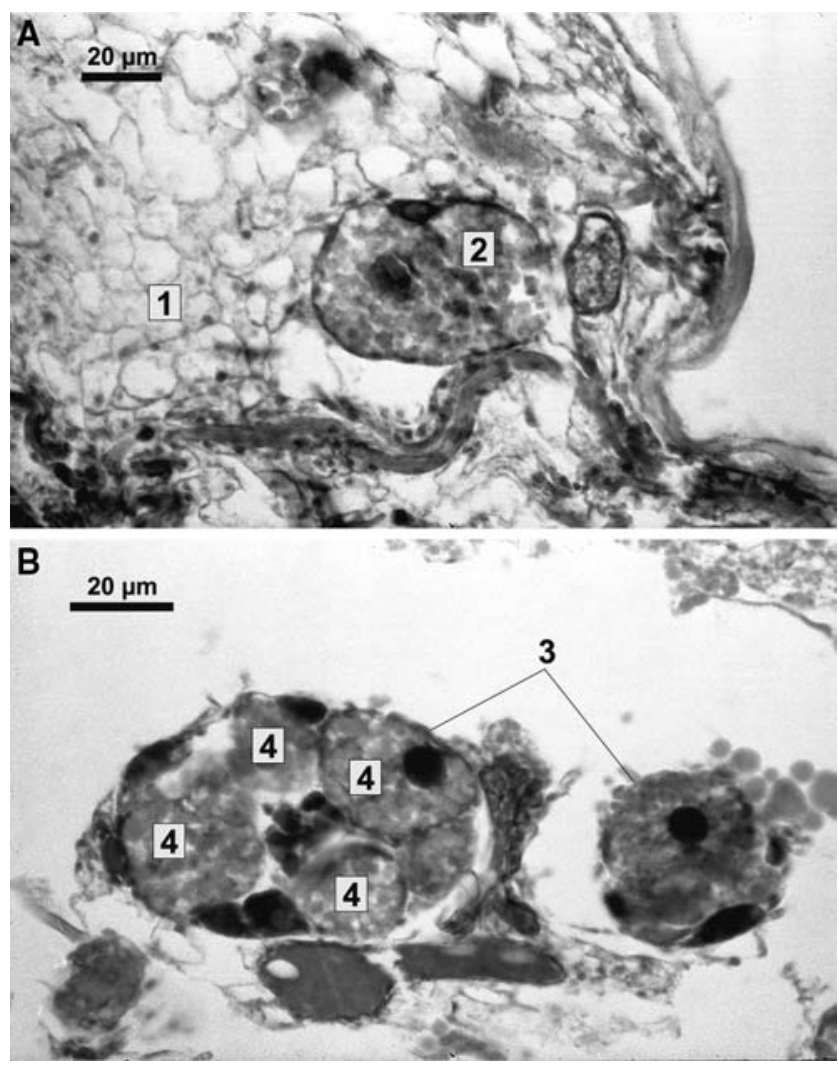

Fig. 7 Micrographs showing some female reproductive structures in Notobalanus flosculus. a Well-developed basal tissue (1) and section of an ovisac (2). b Transversal section of two finger-like prolongations of an ovisac (3), with maturing oocytes (4)

Bridges Islands, 6-8 months after settlement, after July 1997 (Fig. 4).

We attribute differences in growth among the two sites and $P$. granulosa carapaces to differences in food availability. In the harbour, where growth was fastest and barnacles attained the largest sizes, the concentration of suspended particles - and thus probably food availability - was maximal, as shown by the Secchi disk depths. Low tidal currents in the range $0.1-1.0 \mathrm{~m} \times \mathrm{s}^{-1}$ make the surface production available to benthic filterfeeders at a few metres within an hour or less (Wolff 1977). Moreover, water discharges from numerous rivers and streams, mainly in summer after snow melting (Iturraspe et al. 1989), enrich the organic matter content in the Bahía Ushuaia. Greater Secchi disk depths from the Bridges Islands show that this is a more oligotrophic environment than the harbour. This feature along with the high predation pressure exerted by snails and sea stars would turn the Bridges Islands into a disadvantageous habitat for barnacles.

Food availability for epizoic barnacles on $P$. granulosa could increase in several ways: (a) by resuspension of particles from the bottom associated with crab movements; (b) by taking advantage of the organic wastes from the crabs' own food; or (c) by crabs actively selecting and staying in more productive areas. In addition, predation risk could be reduced when barnacles are attached to a mobile substrate, which has virtually no predators. Barnacle density on tiles from the harbour was similar to that onto $P$. granulosa carapaces and significantly higher than that on tiles from Bridges Islands between 1995 and 1998 (Lovrich et al. 2003), in spite of $P$. granulosa density being greater around Bridges Islands than in the harbour. It is probably a combination of different factors which favours growth of epizoic barnacles compared with barnacles attached to artificial substrates within the Bridges Islands area.

Barnacles with oocytes at any stage of development between March and September will probably produce at least one brood before the molt of the basibiont male crabs, mainly in December. However, no barnacles with eggs, embryo or larvae within the mantle cavity were found in this study. This could indicate that no sexually mature individuals were present after September, when nauplii larvae are very abundant in plankton samples from the Beagle Channel (G.A. Lovrich, unpublished data), or, most likely, that individuals sampled had already released their nauplii. The duration of embryo development and/or the permanence of the larvae in the mantle could be too short to allow for a detection of brooding individuals by monthly sampling. For example, the incubation period of Balanus rostratus is 2 weeks at $\sim 43^{\circ} \mathrm{N}$ (Korn 1985). Brooding in Pollicipes pollicipes (Scalpellomorpha) lasts between 28 days and 96 days, depending upon the individual size and crowding level (Cruz and Araújo 1999). The estimated time for embryonic development in this species is 25 days. As a rule, in several species of Balanoidea, the release of nauplii follows closely the spring diatom bloom although embryos are ready to hatch long before (Barnes 1989).
Table 1 Description of female maturation stages

\begin{tabular}{lll}
\hline Stage & Reproductive state & Histological description \\
\hline I & Immature & Absence of basal tissue \\
II & Immature & Basal tissue scarcely developed \\
III & Immature & Well-developed basal tissue, with storage cells \\
IV & Beginning & Presence of immature or basophilic previteline oocytes \\
& & (diameter $<120 \mu \mathrm{m}$ ) in the ovarioles \\
& (finger-like structures in contact with the basal tissue) \\
V & Advanced & Mature oocytes in the ovarioles, \\
& & with a diameter of ca. 120 $\mu \mathrm{m}$. Some oocytes \\
& Bhowed ameboid proccesses \\
VI & Breeding & Presence of embryos within the mantle cavity
\end{tabular}


Table 2 Size ranges, collection dates and maturity status of Notobalanus flosculus attached to false king crab carapaces and to artificial collectors in two locations of the Beagle Channel: Ushuaia Harbour and Bridges Islands

\begin{tabular}{|c|c|c|c|c|}
\hline $\begin{array}{l}\text { Size ranges } \\
\text { (mm OD) }\end{array}$ & Collection dates & $\begin{array}{l}\text { Sexual } \\
\text { maturity } \\
\text { stage }\end{array}$ & Origin & $\begin{array}{l}\text { Number of } \\
\text { individuals }\end{array}$ \\
\hline $2.34-3.01$ & $\begin{array}{l}\text { 03 June } 1998 \\
22 \text { Aug } 1998\end{array}$ & I & P. granulosa & 2 \\
\hline $2.51-5.34$ & $\begin{array}{l}27 \text { May } 1999 \\
12 \text { July } 1999 \\
29 \text { Sep } 1999\end{array}$ & II & P. granulosa & 5 \\
\hline $2.00-4.18$ & $\begin{array}{l}3 \text { Jun } 1999 \\
13 \text { Oct } 1998 \\
27 \text { May } 1999 \\
29 \text { Sep } 1999\end{array}$ & III & P. granulosa & 9 \\
\hline $2.84-5.34$ & $\begin{array}{l}27 \text { Mar } 1998 \\
22 \text { Aug } 1998 \\
12 \text { Jul } 1999 \\
29 \text { Sep } 1999\end{array}$ & IV & P. granulosa & 10 \\
\hline $5.18-6.01$ & 12 Jul 1999 & V & P. granulosa & 2 \\
\hline $1.00-3.51$ & $\begin{array}{l}5 \text { Jan } 1999 \\
10 \text { Feb } 1999 \\
17 \text { Aug } 1999 \\
20 \text { Sep } 1999\end{array}$ & I & Ushuaia Harbour & 10 \\
\hline $3.17-3.34$ & $\begin{array}{l}19 \text { Apr } 1999 \\
26 \text { May } 1999 \\
17 \text { Aug } 1999\end{array}$ & II & Ushuaia Harbour & 3 \\
\hline $2.00 *$ & 19 Apr 1999 & III & Ushuaia Harbour & 1 \\
\hline $0.84-1.84$ & $\begin{array}{l}10 \text { Feb } 1999 \\
5 \text { Mar } 1999 \\
19 \text { Apr } 1999 \\
24 \text { May } 1999\end{array}$ & I & Bridges Islands & 6 \\
\hline $1.00 *$ & 10 Feb 1999 & II & Bridges Islands & 1 \\
\hline
\end{tabular}

The asterisk (*) indicates that only one individual in that sexual maturity stage was collected from that site
The occurrence of $N$. flosculus with mature oocytes on male $P$. granulosa clearly shows that at least a proportion of the epizoic barnacles attains sexual maturity. While ovigerous females of $P$. granulosa molt biennially (Lovrich and Vinuesa 1993), juveniles and males present a molting scheme that varies with size: crabs $10-40 \mathrm{~mm}$ CL molt twice a year, while crabs $40-57 \mathrm{~mm}$ CL molt only once a year (Lovrich and Vinuesa 1995). Male $P$. granulosa $55-80 \mathrm{~mm}$ CL molt once a year in December, whereas at least $20 \%$ of male P. granulosa $>80 \mathrm{~mm}$ CL may skip their annual molt and molt biennially (Lovrich et al. 2003). Similarly, all mature females, i.e. females $>60 \mathrm{~mm}$ CL, molt biennially because the embryogenesis lasts 18-22 months (Lovrich and Vinuesa 1993). The potential of epizoic barnacles to reproduce depends on the time of settlement and on the probability that large males of $P$. granulosa skip their annual molt. The reproductive potential of epizoic $N$. flosculus is clearly limited by the size of its host, since the larger the crab, the longer is the intermolt period.

Among barnacles from collectors that were studied histologically, a total of eight individuals from the harbour were $\geq 2.84 \mathrm{~mm}$ DO (the smallest barnacle with oocytes found), four of which were sampled in August and September 1999. The absence of oocytes in the gonads of these individuals (Table 2) indicates that oocyte development in $N$. flosculus is initiated at an age of more than 9-10 months, independent of the size attained. For obtaining conclusive evidence on this subject, a larger set of individuals has to be studied. Alternatively, breeding in the harbour could be affected by the presence of contaminants such as the heavy metals iron, lead or copper (Amin et al. 1996). Due to the impossibility for barnacles to settle on recently molted $P$. granulosa suggested by Lovrich et al. (2003), and to the fact that maturation takes at least 9-10 months, only barnacles attached to crabs that skip the annual molt have the potential for reaching sexual maturity. Minimum ages needed for maturation vary between 6 weeks and $\sim 9$ 10 months in Chtamalus spp., 20-24 months in Tetraclita spp., and 1 month and 3 years in Balanus spp. (Barnes 1989 and references therein).

The relation between the potential for reaching sexual maturity and the molting periods of the basibionts was treated for only a few other species of barnacles. Dawson (1957) suggested that the presence of mature barnacles on Penaeus setiferus is limited to the winter period, when the molt frequency of the shrimp decreases. The early sexual maturation of Octolasmis corr on the gills of Scylla serrata, attained at the age of 2 weeks, may be an adaptation to maximise the reproductive output, increasing both the egg number that an epibiont may release and the number of potential basibionts (Jeffries et al. 1985). This strategy allows $O$. corr to colonise young crabs, with short intermolt periods. A few other authors discussed the benefits derived from the ecological association between epibiont barnacles and their basibionts. The pedunculate barnacle Trilasmis fissum hawaiense would be protected from fishes and predatory crustaceans by colonising the third maxiliped of the spiny lobsters Palinurus japonicus and P. penicillatus (Bowers 1968). After an extraordinary settlement 
pulse of Balanus crenatus only a few barnacles attached to inert substrates in the sublittoral zone remained alive by the end of summer, while barnacles attached to Nephrops norvegicus from the same area remained alive (Barnes and Bagenal 1951). These authors suggested that survival of epibionts could result from a "protective action" offered by the lobsters, or from the absence of predators in the muddy habitat of $N$. norvegicus.

In this paper, we proposed two ways in which the barnacle $N$. flosculus can profit from settlement on the carapace of $P$. granulosa: increased food availability and decreased predation risk.

Acknowledgements This article is dedicated to the memory of Dr. Paulo Young, deceased the 30 May 2004, who confirmed the identity of the barnacle species. We thank M.C. Romero, V. de la Balze, A. Chizzini, A. Ferlito, M.V. García, and F. Tapella for their help in the laboratory or in the field; the Pesquera del Beagle S.A., which allowed our onboard sampling; J. Lancelotti for programming the Permutation Test; and the reviewers for providing useful comments on the manuscript. This work was financed by a grant from the International Foundation for Science (Stockholm, Sweden, A2507/1) and by the Universidad de Buenos Aires (UBACyT JX28).

\section{References}

Abelló P, Macpherson E (1992) Epibiosis and rhizocephalan infestation patterns in relation to the reproductive biology of Lithodes ferox (Filhol 1885) (Anomura: Lithodidae). J Crustacean Biol 12:561-570

Abelló P, Villanueva R, Gili JM (1990) Epibiosis in deep-sea crab populations as indicator of biological and behavioural characteristics of the host. J Mar Biol Assoc UK 70:687-695

Amin O, Ferrer L, Marcovecchio J (1996) Heavy metal concentrations in literal sediments from the Beagle Channel, Tierra del Fuego, Argentina. Environ Monit Assess 41:219-231

Balestrini C, Manzella G, Lovrich G (1998) Simulación de corrientes en el Canal Beagle y Bahía Ushuaia, mediante un modelo bidimensional. Servicio de Hidrografía Naval, Depto. Oceanografía, Inf Téc 98:1-58

Barnes M (1989) Egg production in cirripedes. Oceanogr Mar Biol Annu Rev 27:91-166

Barnes M (1992) The reproductive periods and condition of the penis in several species of common cirripedes. Oceanogr Mar Biol Annu Rev 30:483-525

Barnes H, Bagenal TB (1951) Observations of Nephrops norvegicus and on an epizoic population of Balanus crenatus Brug. J Mar Biol Assoc UK 70:687-695

Bowers RL (1968) Observations on the orientation and feeding behaviour of barnacles associated with lobsters. J Exp Mar Biol Ecol 2:105-112

Calcagno JA, López Gappa JJ, Tablado AJ (1997) Growth and production of the barnacle Balanus amphitrite in an intertidal area affected by sewage pollution. J Crustacean Biol 17:417-423

Calcagno JA, Lovrich GA (2000) First record of Notobalanus flosculus (Darwin, 1854) (Cirripedia, Archaeobalanidae) from the South Atlantic coast of South America. Crustaceana. DOI $10.1163 / 156854000504309$

Cruz T, Araújo J (1999) Reproductive patterns of Pollicipes pollicipes (Cirripedia: Scalpellomorpha) on the southwestern coast of Portugal. J Crustacean Biol 19:260-267
Dawson CE (1957) Balanus fouling on shrimp. Science 126:1068

Gabe M (1968) Techniques histologiques. Masson Ed, Paris

Gili JM, Abelló P, Villanueva R (1993) Epibionts and intermoult duration in the crab Bathynectes piperitus. Mar Ecol Prog Ser 98:107-113

Heat DJ (1976) The distribution and orientation of epizoic barnacles on crabs. Zool J Linn Soc Lond 59:59-67

Iturraspe R, Sottini R, Schroeder C, Escobar J (1989) Hidrología y variables climáticas del Territorio de Tierra del Fuego. Información básica. Contrib Cient CADIC 7:1-196

Jeffries WB, Voris HK, Yang CM (1985) Growth of Octolasmis cor (Aurivillius 1892) on the gills of Scylla serrata (Forskal, 1755). Biol Bull 169:291-296

Korn OM (1985) The reproductive cycle of the barnacle Balanus rostratus in Peter the Great Bay, Sea of Japan. Biol Morya 3:36-43

Laihonen P, Furman ER (1986) The site of settlement indicates commensalism between bluemussel and its epibiont. Oecologia 71:38-40

Legendre P, Legendre L (1998) Numerical ecology. Second english edition. Developments in environmental modelling 20. Elsevier, Amsterdam

Lovrich GA (1997) La pesquería mixta de centollas Lithodes santolla y Paralomis granulosa (Anomura: Lithodidae) en Tierra del Fuego, Argentina. Invest Mar Valparaíso 25:4-57

Lovrich GA, Calcagno JA, Smith BD (2003) The barnacle Notobalanus flosculus as an indicator of the intermolt period of the male lithodid crab Paralomis granulosa in the Beagle Channel, Argentina. Mar Biol. DOI 10.1007/s00227-003-1033-8

Lovrich GA, Vinuesa JH, Smith BD (2002) Growth, maturity, and mating of male Lithodes santolla (Decapoda: Anomura) in the Beagle Channel, Argentina. In: Paul AJ, Dawe EG, Elner R, Jamieson JS, Kruse GH, Otto RS, Sainte-Marie B, Shirley TC Woodby D (eds) Crabs in cold water regions: biology, management, and economics. University of Alaska Sea Grant, AKSG-02-01, pp 147-168

Lovrich GA, Vinuesa JH (1993) Reproductive biology of the false southern king crab (Paralomis granulosa Lithodidae) in the Beagle Channel, Argentina. Fish Bull 91:664-675

Lovrich GA, Vinuesa JH (1995) Growth of juvenile false southern king crab Paralomis granulosa (Anormura, Lithodidae) in the Beagle Channel, Argentina. Sci Mar 59:87-94

Manly BFJ (1994) Randomization and Monte Carlo methods in biology. Chapman and Hall, London

Paul JM, Paul AJ (1986) Encrusting barnacles as ageable tags on Gulf of Alaska Chionoecetes bairdi (Decapoda). Alaska Sea Grant Rep 86-02:1-28

Pohle G (1989) Gill and embryo grooming in lithodid crabs: comparative functional morphology based on Lithodes maja. In: Felgenhauer BE,Watling L,Thistle $\mathrm{AB}$ (eds) Functional morphology of feeding and grooming in Crustacea. In: Schram FR (gen ed) Crustacean issues 6. Balkema, Rotterdam, pp 7594

Venerus LA (2000) Reclutamiento, crecimiento y madurez sexual de Notobalanus flosculus (Darwin 1854) (Cirripedia, Thoracica) como epibionte del centollón Paralomis granulosa (Jacquinot, 1847) (Decapoda, Anomura) en el Canal Beagle, Ushuaia, Argentina. "Licenciatura" Thesis diss, Facultad de Ciencias Exactas y Naturales, Universidad de Buenos Aires

Wahl M (1989) Marine epibiosis. I. Fouling and antifouling: some basic aspects. Mar Ecol Prog Ser 58:175-189

Wolff WJ (1977) A benthic food budget for the Gravelingen Estuary, the Netherlands, and a consideration of the mechanisms causing high benthic secondary production in estuaries. In: Coull BC (ed) Ecology of marine benthos. Belle W. Baruch library in marine science 6, University of South Carolina Press, Columbia, pp 267-280 